Document downloaded from:

http://hdl.handle.net/10251/104013

This paper must be cited as:

Moreno Pérez, OM.; Marcossi, GP.; Ortiz Miranda, D. (2017). Taking stock of the evolution of the biodiesel industry in Brazil: Business concentration and structural traits. Energy Policy. 110:525-533. doi:10.1016/j.enpol.2017.09.001

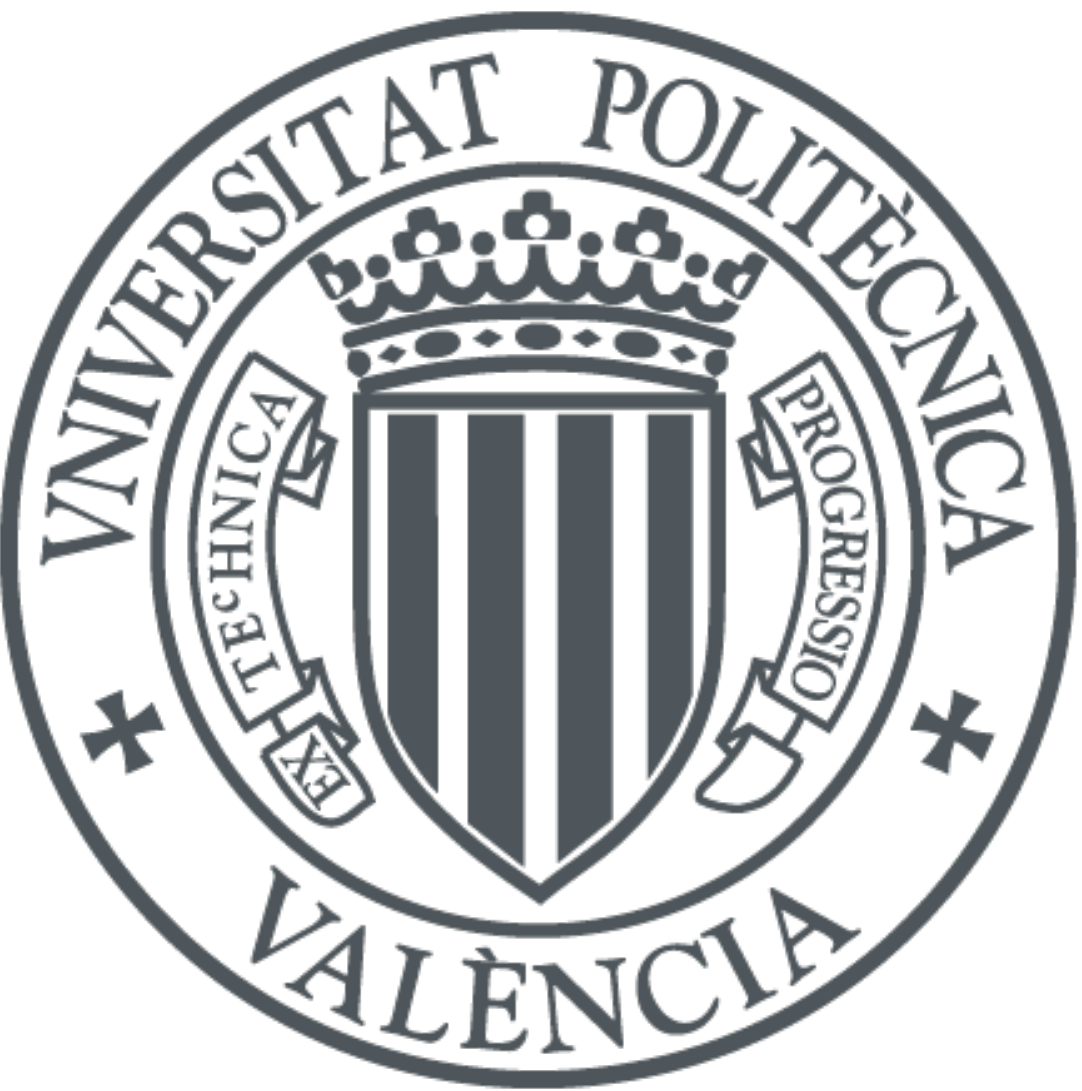

The final publication is available at

https://doi.org/10.1016/j.enpol.2017.09.001

Copyright Elsevier

Additional Information 


\title{
Taking stock of the evolution of the biodiesel industry in Brazil: Business concentration and structural traits
}

Olga M. Moreno-Pérez ${ }^{a}$

Gisele P.C. Marcossia

Dionisio Ortiz-Miranda ${ }^{a}$

\author{
a Group of International Economy and Development \\ Department of Economics and Social Sciences. Universidad Politécnica de Valencia. \\ Camino de Vera, s/n. 46022 Valencia (Spain)
}

\begin{abstract}
The Brazilian biodiesel industry has rapidly developed under the National Biodiesel Production and Use Programme (PNPB) launched in 2004, which is to be replaced by a new regulatory framework that is now under discussion. This paper aims to take stock of the evolution of the structure of the biodiesel industry in this country under the implementation of the PNPB -between 2005 and 2016- and to understand its current traits. The research combines a dynamic analysis of the industrial concentration indexes (closing the time gap with previous studies on this matter) and a multivariate analysis of the productive characteristics of the biodiesel plants operating in 2016. Results show that, following a period of de-concentration between 2005 and 2011, the industry entered in a stage of certain stability in the concentration indexes. This picture disguises the exit of biodiesel plants and firms from this market and a number of business acquisitions in the last period. The static analysis has allowed for the identification of different 'business models' regarding the scale of the plants and the diversification/specialisation patterns of both raw materials and outputs.
\end{abstract}

Keywords: Brazil; biodiesel; regulatory framework; industrial concentration; industrial structure 


\section{Introduction}

In December 2016, the Brazilian Administration launched a new regulatory framework for the biofuel sector, a programme named RenovaBio 2030, which integrates biodiesel and bioethanol production. The new strategic policy is aimed to discuss biofuel sustainability involving conventional and secondgeneration biofuels, establish the trading rules and encourage investments in this industry until 2030. The ambition is to expand the production of renewable fuels in the country, in accordance with the Brazilian commitments at COP21 (UN Climate Conference) of increasing the share of sustainable biofuels to around $18 \%$ of the overall national energy mix by 2030 . At the time of writing (April 2017) the programme has been submitted for public consultation.

Regarding the biodiesel industry, in which this paper is focused, the new programme would entail a profound change in the legal framework that has driven this sector in Brazil for more than one decade. The National Biodiesel Production and Use Programme (PNPB), which was launched in 2004, has boosted an rise in biodiesel production until making Brazil the second world producer after USA today (REN21, 2016). The academic literature has paid great attention to both the development and the economic, social and environmental results of this programme, as a worldwide benchmark for national biofuel policies (see, among others, Cremonez et al., 2015; Oliveira and Coelho, 2016; Rico and Sauer, 2015; Nogueira and Silva, 2013; Padula et al., 2012).

Some studies conducted at the beginning of this decade analysed the specific issue of the business concentration in the biodiesel industry throughout the initial stage of expansion of this market (Tanaca and de Souza, 2010; Leonardi et al., 2011; Dos Santos and Padula, 2012). However, these works have not been updated, despite the changes that this sector has undergone thereafter - e.g. some reforms undertaken in the PNPB in 2012, the increasing competition among biodiesel plants and the business movements that have taken place over the last few years, as it will be seen below.

In this context, we have carried out a research with two main objectives. First, to assess the evolution of the structure of the Brazilian biodiesel industry throughout the entire PNPB implementation period, 
from 2005 to 2016, paying special attention to the business concentration. Second, to examine the main traits of the structure of the biodiesel industry today, as it is the starting point of a new stage whose regulatory framework is now under discussion. Special attention will be paid to the feedstocks utilised to obtain biodiesel and other outputs produced by the firms operating in this sector.

The remainder of this paper is structured as follows. In Section 2 the methodology of this research is clarified. In Section 3 we comment the overall functioning of the PNPB and its main results based on the scientific literature, what will help to contextualize the analysis and provide explanatory elements to the following sections. The two specific objectives specified above are tackled in Sections 4 and 5, respectively, and conclusions are given in Section 6.

\section{Methodology}

This study has been based on information obtained from a wide variety of sources, due to the limitations presented by official statistics, what has been a major challenge. The National Agency of Petroleum, Natural Gas and Biofuels (ANP) registers the volumes of biodiesel sold in the auctions, as well as the industrial units participating in the bidding process. The same office issues a monthly report informing on the biodiesel production and the feedstocks utilised at the regional level, the production capacity of each biodiesel mill and the firms authorised to build new plants or to expand/modify the existing units. This information is complemented with the monthly reports published by MME on the bioethanol and biodiesel market.

However, the governmental agencies do not consistently track or record the merger and acquisition movements that have taken place in this industry - a relevant information to know the way the business structure has evolved. Similarly, the information on the biodiesel plants that temporary or definitely retire from this market is not always up-to-date, and there is no comprehensive information on the feedstocks utilised for biodiesel production. 
In order to address these limitations, other sources such as press releases, websites of related institutions (i.e. the Brazilian Association on Vegetal Oil Industries - Abiove; the National Supply Company - CONAB) and the informative journal BiodieselBr were consulted. The website of firms producing biodiesel, when available, provided further details on the type of feedstocks utilised and the outputs, other than biodiesel, manufactured by the company. Additionally, 10 telephone inquiries were made to the power plants for which this information was insufficient or not updated in the consulted sources.

Regarding the analytical approach of this research, the changes in the concentration of the firms participating in this industry have been assessed by means of two types of indexes. First, the Concentration Ratios (CR) proposed by Bain (1951), who considered the business control in the hands of a limited number of firms as a key aspect to characterise an industry structure. They are calculated from the expression

$$
C R(k)=\sum_{i=1}^{k} S_{i}
$$

where $C R(k)$ is the concentration ratio of the largest $k$ industries and $S_{i}$ the market share of the $i$ industries. Some common estimates are $\mathrm{CR}(2), \mathrm{CR}(4)$ and $\mathrm{CR}(8)$.

Second, the Herfindahl-Hirschman Index (HHI) (see Hirschman, 1964), defined as:

$$
H H I=\sum_{i=1}^{N} S_{i^{2}}
$$

which ranges from 0 (many small companies) to 1 (monopoly). A HHI below 0.15 indicates an unconcentrated industry, between 0.15 and 0.25 a moderately concentrated market and above 0.25 a 
concentrated one ${ }^{1}$. Whereas $C R(k)$ informs on the degree of competition of the market focusing only on the largest firms, $\mathrm{HHI}$ provides a picture of the distribution of the firm size in an industry. This paper combines the four mentioned indexes to construct a more comprehensive yearly evolution.

Later, with the purpose of exploring and describing the structure of the Brazilian biodiesel industry today, a Multiple Correspondence Analysis ${ }^{2}$ (MCA) has been performed with SPSS Statistics version 20. MCA is a multivariate data analysis technique that simplifies a dataset of observations (here biodiesel plants) described by more than two nominal variables into a small number of dimensions - similarly to what Principal Component Analysis performs with quantitative variables. The last step of the analysis was to combine the MCA with an agglomerative hierarchical clustering (Carvalho, 2008), in order to identify relatively homogeneous groups of biodiesel plants. Further details on this procedure are exposed in Section 5.

\section{The functioning and expansion of the biodiesel sector in Brazil}

The effective introduction of biodiesel into the Brazilian energy matrix started with the PNPB, an interministerial programme created by Federal Law no. 11097/2005 and coordinated by the MME. It was aimed at fostering the biodiesel production and consumption in the country in a sustainable way, both technically and economically, focusing on social inclusion and regional development (MME, 2015). This regulatory framework was supported on a set of instruments aimed at driving the way the economic agents participating in the biodiesel supply chain operate and interact with each other, which are explained briefly below.

First, the programme introduced blending mandates to stimulate the consumption and production of biodiesel in Brazil. A voluntary blending percentage of $2 \%$ of biodiesel into petroleum diesel (denoted as B2) was authorised for the first time in 2005 , but it turned mandatory in 2008 for all of the diesel

\footnotetext{
${ }^{1}$ Thresholds set by the US Department of Justice and the Federal Trade Commission https://www.justice.gov/atr/horizontal-merger-guidelines-08192010 (accessed in December 2016).

${ }^{2}$ See the classic text of Greenacre (1984) for a comprehensive explanation of this method.
} 
commercialised nationwide. The Government increased the blending rates gradually thereon to reach B7 in November 2014, and the forthcoming targets are B8 in March 2017, B9 in March 2018 and B10 in March 2019. Each biodiesel plant is authorised by the ANP to produce a maximum volume of biodiesel per year, although they produce much below their full nameplate capacity. By 2016, the total amount authorised was $3.68 \mathrm{Mm}^{3}$, but the utilisation factor was $50.3 \%$ (ANP, 2017).

Second, distributors buy biodiesel in auctions held on a bimonthly basis. The plants are the bidders, and offer biodiesel with a discount to a maximum reference price per region set by the ANP. Until the $25^{\text {th }}$ auction, biodiesel B100 (without blending) was sold by the mills to Petrobras, and later reauctioned between it and the authorised distributors. However, the Ordinance MME 276 of 2012 provisioned that from the $26^{\text {th }}$ auction, held in June 2012, distributors would choose the suppliers to whom they would buy the biodiesel. This change in the auction format was aimed to reduce the public intervention and encourage competition among biodiesel plants, as distributors would select the plants that best fit their needs in terms of logistics, price and quality. Regional restrictions were eliminated and the volume of biodiesel bought would no longer be defined previously by the ANP. Petrobras still intermediates the transaction and charges a fixed amount per cubic meter.

Third, a special tax system is aimed promote the diversification of feedstocks used for biodiesel, particularly in the poorest areas of the country. Reductions are set for biodiesel producers in federal taxes, PIS/PASEP and COFINS ${ }^{3}$, on the condition they utilise palm or castor oil in the North, Northeast and Semi-arid regions. The cultivation of these crops is encouraged as they adapt well to small farms and to the Amazonian conditions (Cremonez et al., 2015; Bergmann et al. 2013; Cesar et al. 2013) thus contributing to the goals of social inclusion and regional development.

\footnotetext{
${ }^{3}$ PIS/PASEP (Programme of Social Integration/Programme of Patrimony Formation of Public Servants), which are social contributions payable by legal entities, and COFINS (Contribution to the Social Security Funding), the federal tax levied on the gross revenues of enterprises.
} 
Fourth - and connected with the former instruments - social inclusion was promoted by the Social Fuel Seal (SFS), a certification scheme awarded by the Ministry of Agricultural Development ${ }^{4}$ (MDA) aimed at upgrading small farmers in the biodiesel value chain, also prioritising the less developed areas of the country. Additional benefits in the federal taxes were established for biodiesel plants that acquired a minimum percentage of their feedstocks (between $15 \%$ and $40 \%$, depending on the region) from family farmers and provided them with technical assistance. These plants had also priority to sell their biodiesel in the auctions. In 2015, animal fat was also included in SFS (Ordinance MDA 337 of 18 September).

The results of the PNPB have been ambivalent. The increasing mandatory blends have fostered the biodiesel production in the country, which went from $736 \mathrm{~m}^{3}$ in 2005 to $3.67 \mathrm{Mm}^{3}$ in 2016 (Fig. 1). Production has continuously grown since the programme came into force, excepting in 2016, when it slightly declined due to the economic crisis (Barros, 2016).

However, the PNPB has failed in promoting the diversification of feedstocks. Soybeans are still, by far, the most important raw material- according to MME (2016), $77.6 \%$ of the Brazilian biodiesel was obtained from it (until October 2016). This prevalence is related with the increasing concentration of biodiesel production in the Central West and the South of the country (Fig. 1), where the soybean agroindustry based on modern, monoculture and large-scale plantations is consolidated. The MME informs that $86 \%$ of Brazilian biodiesel was produced in those two regions in 2016, whereas this percentage was $71 \%$ in 2010 . The most outstanding progress in this period was registered by the South (from $28 \%$ to $45 \%$ of the production share), whereas the North and Northeast reduced their participation, which was already poor in 2010 (from 11\% to 8\% in 2016). Despite the emphasis placed by the PNPB in fostering biodiesel production in the latter two regions, only four mills continue to operate there. The changes in the geographical patterns of distribution of biodiesel plants not only

\footnotetext{
${ }^{4}$ This Ministry was abolished in May 2016, and its competences transferred to the Ministry of Social and Agrarian Development.
} 
respond to the feedstocks utilised, but also to the preference to locate them close to the consumption centres (Oliveira et al., 2016).

Fig. 1. Biodiesel production and delivery by regions

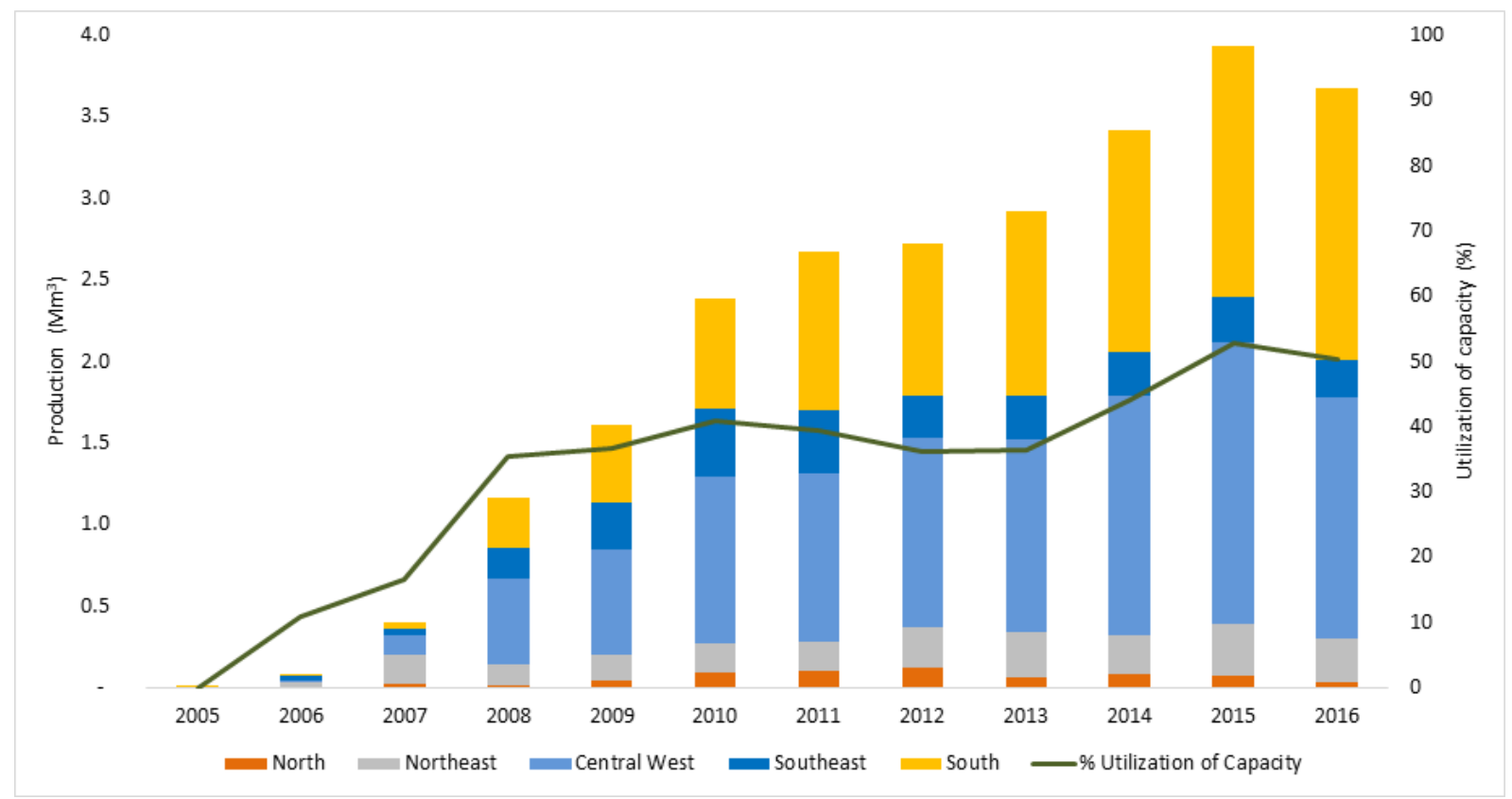

Source: Authors' elaboration based on the biodiesel auctions reports elaborated by the ANP from 2005-2016 (www.anp.gov.br)

The only feedstock alternative to soybean that has increased significantly in importance in recent years is beef tallow, a by-product of the strong Brazilian meat processing industry, which represented $15.5 \%$ of the biodiesel production in 2016 (until October). Thus, the raw materials which have prevailed are those organised in well-established supply chains that guarantee the stability of supply in reasonable quantity and quality, which have low costs and obtain important revenues from other co-products.

In contrast, the use of other oilseeds did not reach 4\% of all the biodiesel produced in 2016 (MME, 2016). The use of palm and castor oil, incentivised by the PNPB, continues to be irrelevant due to the significant disadvantages it presents. Several studies have highlighted the low agricultural yields, the 
need for an intensive use of scarce labour in the North and Northeast, the logistical costs and a number of technical limitations of its use to obtain biodiesel (Oliveira and Coelho, 2016; Nogueira et al. 2016; Padula et al., 2012). Moreover, these feedstocks have more profitable uses - food in the case of palm; chemical, cosmetic or pharmaceutical in the case of castor (Stattman et al., 2013; Oliveira and Coelho, 2016).

The above facts relate to what may be considered a failure to meet the social inclusion objective. The number of small farmers participating in SFS reached a peak of 100,000 in 2011, and felt every year thereafter to be 72,500 in 2015 (MDA, 2016) - very far from the political target of 200,000 producers. Significantly, the farmers who have left SFS were mainly located in the Northeast, and those still involved are concentrated in the South, where they are well organised into cooperatives (Stattman and Mol, 2014). Important dysfunctions have been identified in the SFS operation (Marcossi and Moreno, 2017). In the North and Northeast, biodiesel plants have failed to involve family farmers from their own territories, as they buy feedstock from smallholders located in the other regions (Silva et al., 2014). Much of the castor and palm oil produced there is resold by power plants to buy soybean as feedstock for biodiesel (César and Batalha, 2013). The diversion of soybean oil transacted within SFS to food processing is also a widespread practice in Brazil (Marcossi and Moreno, 2017).

\section{The evolution of the structure of the biodiesel industry in Brazil}

The expansion of biodiesel production run parallel to the increase in the number of plants operating in the country, particularly in the early years of implementation of the programme (Fig. 2). 
Fig. 2. Evolution of number of biodiesel plants participating in the auctions (with indication of the blending percentage in force), by regions

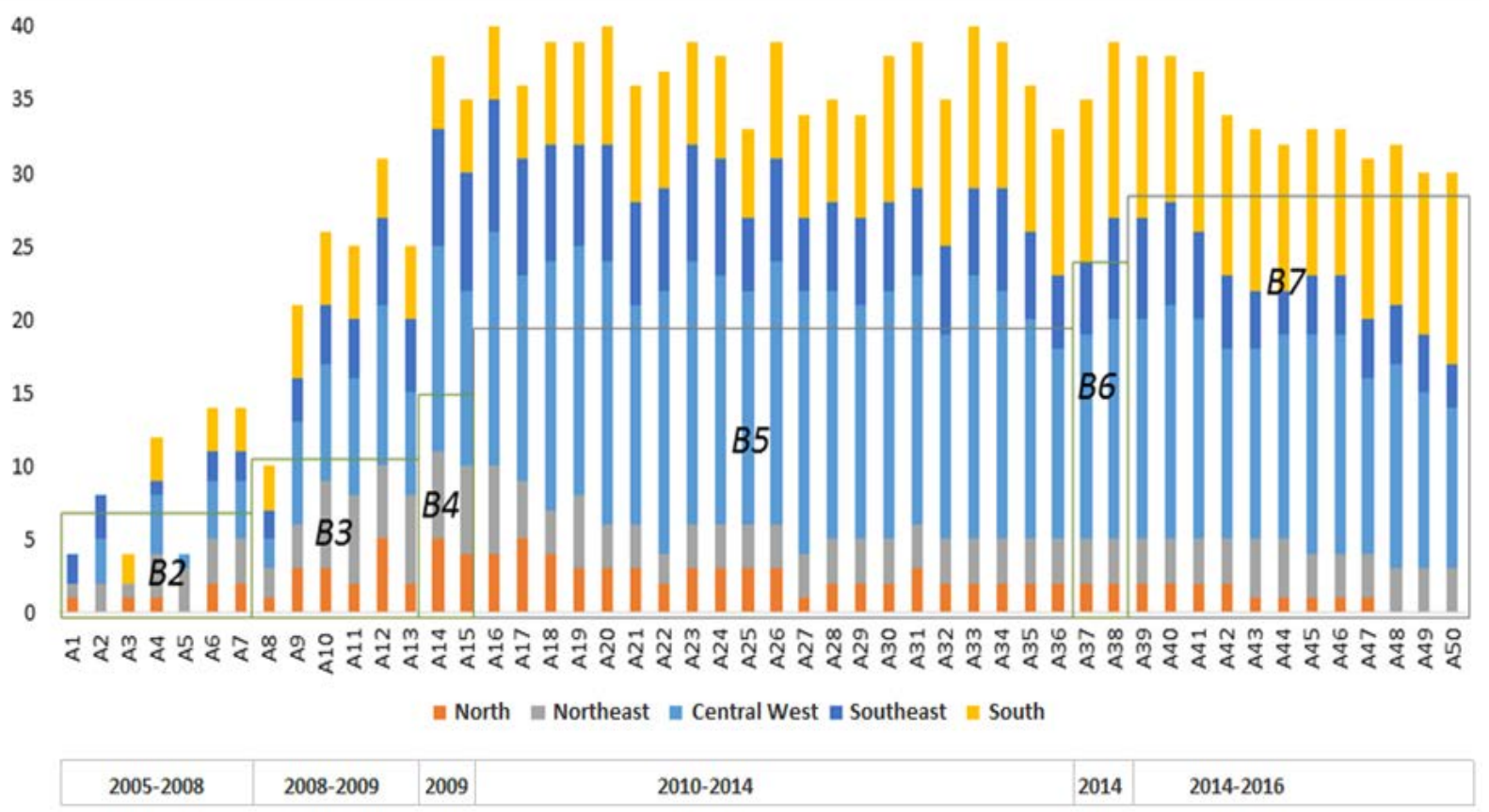

Source: Authors' elaboration based on data from ANP, 2005-2016 (www.anp.gov.br)

Studies conducted so far (see Table 1) coincide in pointing out the high level of concentration shown by this industry when the auctions system started to operate, with very few companies supplying biodiesel. This situation rapidly changed as new firms entered into this market. Using different indexes, these works verified the de-concentration process along the first six years of implementation of the PNPB. 
Table 1. Review of previous studies on the structure of the Brazilian biodiesel industry

\begin{tabular}{|c|c|c|c|}
\hline & Period analysed & Concentration indexes & Methodological approach \\
\hline $\begin{array}{l}\text { Tanaca and de } \\
\text { Souza, } 2010 .\end{array}$ & $\begin{array}{l}\text { From } 1^{\text {st }} \text { to } 17^{\text {th }} \\
\text { auction (years: } \\
2005-2010 \text { ). }\end{array}$ & $\begin{array}{l}C R(4): 1 \Rightarrow 0.473 \\
C R(8): 0.987 \Rightarrow 0.712 \\
H H I: 0.384 \Rightarrow 0.078\end{array}$ & $\begin{array}{l}\text { Indexes are calculated individually for } \\
\text { all bids considering the amount of } \\
\text { delivered biodiesel. } \\
\text { The unit of analysis is the firm, } \\
\text { regardless of whether it has one or } \\
\text { more plants in different locations. }\end{array}$ \\
\hline $\begin{array}{l}\text { Leonardi et al., } \\
2011 .\end{array}$ & $\begin{array}{l}\text { From } 1^{\text {st }} \text { to } 16^{\text {th }} \\
\text { auction (years: } \\
2005-2010)\end{array}$ & $\begin{array}{l}\mathrm{CR}(4): 1 \Rightarrow 0.46 \\
\text { Gini Index: } 0.2 \Rightarrow 0.6\end{array}$ & $\begin{array}{l}\text { Indexes are calculated individually for } \\
\text { any bid (from } 1^{\text {st }} \text { to } 17^{\text {th }} \text { ), considering } \\
\text { the amount of delivered biodiesel. } \\
\text { The unit of analysis is the individual } \\
\text { plant, so that plants in different } \\
\text { locations are considered separately } \\
\text { even if they belong to the same } \\
\text { company. }\end{array}$ \\
\hline $\begin{array}{l}\text { Dos Santos } \\
\text { and Padula, } \\
2012 .\end{array}$ & $\begin{array}{l}\text { From } 2005 \text { to } \\
2010 .\end{array}$ & $\begin{array}{l}\text { CR(2): } 0.905 \Rightarrow 0.239 \\
C R(4): 1 \Rightarrow 0.411 \\
C R(8): 0.999 \Rightarrow 0.669 \\
\text { HHI: } 0.530 \Rightarrow 0.070\end{array}$ & $\begin{array}{l}\text { Indexes are calculated yearly (bids } \\
\text { held in the same year are } \\
\text { aggregated), considering the } \\
\text { produced (not the delivered) biofuel. } \\
\text { The unit of analysis is the firm, } \\
\text { regardless of whether it produces in } \\
\text { one or more plants in different } \\
\text { locations. }\end{array}$ \\
\hline
\end{tabular}

Source: Authors' elaboration from the quoted studies.

However, the authors quoted in the table only observed the structure of the biodiesel industrial park until 2010. The updating of this analysis is precisely one of the main contributions of this paper. With this purpose, we have combined the methodological approaches of these studies, in such a way that:

- Concentration indexes are calculated at the firm level, so that the delivered production of several plants belonging to a same company have been aggregated.

- Indexes are calculated annually, thus all the auctions in a given year have been aggregated.

- Market share has been estimated from the biodiesel production effectively delivered by each firm.

Table 2 shows the evolution of the structure of the biodiesel industry in the entire programme period, from 2005 to 2016. In line with preceding studies, our results reveal a clear trend towards a lower concentration during the first years of development of this market. Some of the new entrants were 
producers of soybean oil that coupled the crushing plant with the biodiesel production; some others rented the crushing plant or directly brought the vegetable oil to other firms (Dos Santos and Padula, 2012). From the early years of the present decade, concentration indexes start to show an apparent stability, what indicates that this industry reached a certain level of 'maturity' characterised by a low level of concentration $(\mathrm{HHI}<0.15)$. However, this picture disguises some remarkable business movements that have taken place in the last period.

Table 2. Structure of biodiesel industry in Brazil, 2005-2016

\begin{tabular}{|cccccccccc|}
\hline Year & CR (2) & CR (4) & CR (8) & HHI & No. firms & $\begin{array}{l}\text { Average } \\
\text { delivery } \\
\text { (m } / \text { firm) }\end{array}$ & $\begin{array}{l}\text { No. } \\
\text { plants }\end{array}$ & $\begin{array}{l}\text { Average } \\
\text { delivery } \\
\text { (m³/plant) }\end{array}$ & $\begin{array}{l}\text { \% Utilised } \\
\text { capacity }\end{array}$ \\
\hline 2005 & 0.80 & 1 & - & 0.383 & 4 & 17,500 & 4 & 17,500 & - \\
2006 & 0.65 & 0.99 & - & 0.273 & 6 & 28,333 & 8 & 21,250 & 12.3 \\
2007 & 0.57 & 0.74 & 0.94 & 0.241 & 16 & 40,312 & 18 & 35,833 & 16.4 \\
2008 & 0.33 & 0.53 & 0.82 & 0.101 & 24 & 30,864 & 31 & 23,895 & 32.4 \\
2009 & 0,25 & 0.46 & 0.73 & 0.080 & 32 & 46,247 & 41 & 36,095 & 41.5 \\
2010 & 0.25 & 0.42 & 0.69 & 0.074 & 38 & 61,023 & 49 & 47,324 & 45.4 \\
2011 & 0.23 & 0.40 & 0.65 & 0.068 & 39 & 65,839 & 48 & 53,494 & 44.4 \\
2012 & 0.23 & 0.42 & 0.68 & 0.069 & 36 & 72,740 & 45 & 58,192 & 39.7 \\
2013 & 0.24 & 0.41 & 0.64 & 0.067 & 37 & 77,056 & 45 & 63,357 & 38.9 \\
2014 & 0.22 & 0.38 & 0.64 & 0.066 & 35 & 93,493 & 42 & 77,911 & 45.6 \\
2015 & 0.21 & 0.39 & 0.65 & 0.066 & 32 & 119,611 & 41 & 93,355 & 54.1 \\
2016 & 0.21 & 0.39 & 0.66 & 0.067 & 26 & 143,534 & 34 & 109,761 & 50.3 \\
\hline
\end{tabular}

Source: Authors' elaboration from the data on biodiesel auctions published by the ANP from 2005 to 2016 (www.anp.gov.br). The utilised capacity is calculated from the MME monthly bulletins in the same period (www.mme.gov.br)

The number of firms bidding in the biodiesel auctions peaked in 2011 to start to descend thereafter, and so did the number of plants. The presence of fewer operators, compatible with the stability of the concentration indicators, points to a certain homogenisation of the size of the firms. As shown in Table 2 , the leading companies did not gain market share significantly at this stage, as there were only slight rebounds of concentration in 2012 and 2016. What some scholars have found is that, while small biodiesel plants (those with less than $80,000 \mathrm{~T}$ of installed capacity) were predominant at the beginning of the auction system, their average scale increased in the last period (Nogueira et al., 2016). 
The drop of the number of firms have responded to two different causes. On the one hand, some firms exited from the biodiesel market between 2012 and 2016 . In this regard, Nogueira et al. (2016) have emphasised the importance of the change of the biodiesel auction model in 2012 (see Section 3), and the subsequent increase in the competition among plants - a competitive pressure that would have benefitted the plants with the lowest fixed costs (Oliveira et al. 2012). Nogueira et al. (2016) also found that the biodiesel prices have approximated to the production costs from 2011 , what has led to a narrowing in the business margins. In the same line, Oliveira and Coelho (2016) have highlighted the drop in the biodiesel prices and linked the closure of plants with the inability to keep up with profit margins, particularly in 2013 and half of 2014. Importantly, the low percentage of utilisation of the productive capacity may also contribute to the exit of firms from this market (Silva Junior, 2013).

On the other hand, the drop in the number of firms responds to acquisitions of some plants by other companies operating in the biodiesel industry. Examples of these movements have been schematized in Fig. 3, which illustrates the intense business dynamism that has characterized this sector in recent years ${ }^{6}$.

Fig. 3. Business acquisitions in the Brazilian biodiesel industry

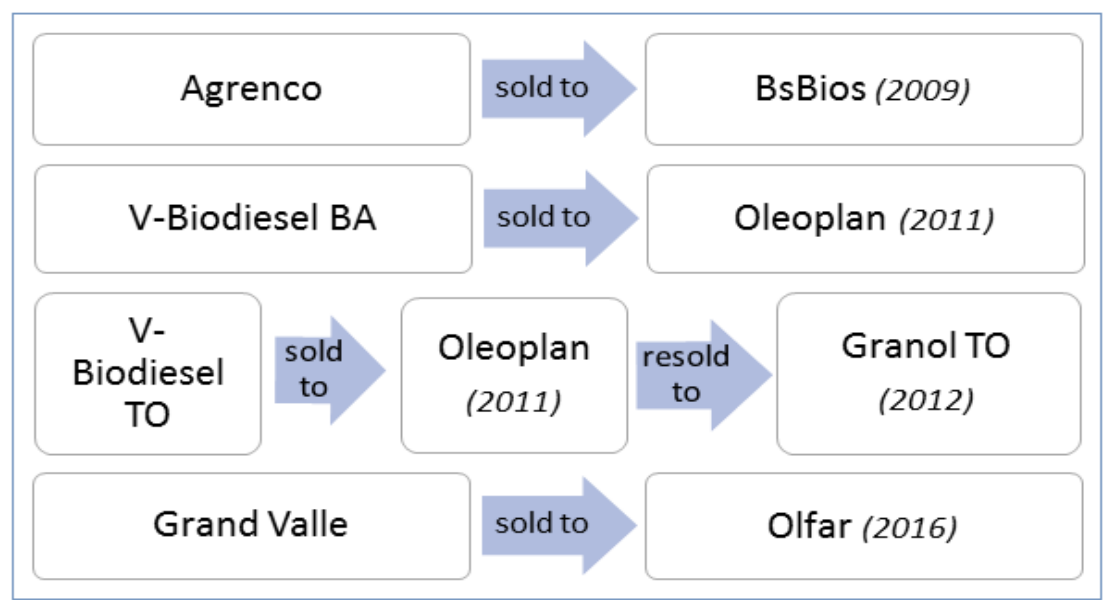

Source: BiodieselBr (2009, 2012, 2014a, 2014b, 2016).

\footnotetext{
${ }^{5}$ The cases of Bio Petro, Bioverde, Fertibom and Biocapital (Southeast region), Grupal, Cooperfeliz, Cooperbio and Biocar (Center West) and Amazonbio (North).

${ }^{6}$ Today there are seven companies that own two or three biodiesel plants, either in the same or in different regions of the country: ADM, BsBios, Caramuru, Granol, Oleoplan, Olfar and PBio.
} 
Finally, these structural changes from 2012 have been parallel to the growth of the biofuel delivered by this industry. In fact, the progressive increase of the blend rates (Figure 2) has been interpreted as a response of the Brazilian authorities to the pressure exerted by the biodiesel companies, given that the idleness of the plants compromises the financial health of this sector (Oliveira and Coelho, 2016). As Table 2 shows, the utilisation factor of the plants have increased over the last years, after reaching a low point in 2013.

\section{The productive structure of the Brazilian biofuel industry in 2016}

This section aims to respond to the second objective of the paper, i.e. bringing to light the structural characteristics of the biodiesel plants at present in operation. Although the basic unit of analysis is the plant rather than the firm, some traits of the firms will be taken insofar as they help to interpret the results. The 34 plants included in this analysis correspond to those that participated in the biodiesel auctions conducted in 2016.

Given that the information publicly available on the power plants is fairly limited, the analysis has been based on three variables on which we have captured data for all the productive units. To obtain this information it was necessary to consult different secondary sources, and in some cases to make direct enquiries to industries (see Section 2). First, we have observed the authorized nominal capacity; as a proxy of the scale of the infrastructures installed; second, the feedstock used to produce biodiesel; and third, the type of outputs manufactured by the firm, which provide an insight of its productive diversification and possible vertical integration. Glycerine and fatty acids have not been considered, as they are coproducts of biodiesel production.

Table 3 shows the categorisation of these variables and the number of plants that fall into each category. The mills that exclusively use soybean as feedstock for biodiesel are distinguished from those using at least another oilseed (soybean is not excluded), and those using animal fats (alone or together 
with vegetable oils). Data show that nearly half of the plants still use soybean as the only raw material for biodiesel production, and one-third use animal fats (typically beef tallow) for this purpose. Regarding the outputs manufactured, the majority of the plants belong to firms that also produced foodstuff (including ingredients for animal feeding), and only a small part was specialised on biodiesel production.

Table 3. Distribution of Brazilian biodiesel plants in categories, $2016(\mathrm{~N}=34)$

\begin{tabular}{|llc|}
\hline \multirow{3}{*}{ Nominal capacity } & Small $\left(<120,000 \mathrm{~m}^{3}\right)$ & 9 \\
& Medium $\left(120,000-200,000 \mathrm{~m}^{3}\right)$ & 11 \\
& Big $\left(>200,000 \mathrm{~m}^{3}\right)$ & 14 \\
\hline \multirow{3}{*}{ Feedstock for biodiesel } & Soybean & 14 \\
& Various Oilseeds & 9 \\
& Vegetal \& Animal Feedstock & 11 \\
\hline \multirow{3}{*}{ Outputs } & Biodiesel & 8 \\
& Biodiesel \& Foodstuff & 20 \\
& Biodiesel \& Non-foodstuff & 6 \\
\hline
\end{tabular}

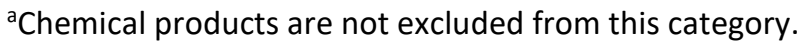
Source: Authors' elaboration.

In order to explore the patterns of relationships of these variables, we performed a MCA that displays the categories in a reduced factor space. The MCA enables a visual representation of the underlying structure of the dataset, in such a way that the closer the category points are, the more related. In our study, the dataset was summarized in two dimensions that explain a mean of $58.5 \%$ of the variance. The joint plot of category points is displayed in Fig. 4.

The chart reveals the close association existing between the category of 'big' biodiesel plants (over $200,000 \mathrm{~m}^{3}$ of authorized capacity), soybean as the only biodiesel feedstock and multiple outputs processed by the firm (biodiesel, foodstuffs and sometimes also chemical products). On the contrary, plants specialized in biodiesel are close to the category of diversified (vegetal and animal) feedstocks. As we move to the left side of the space, the categories of 'medium-sized' and 'small' units are 
successively displayed. In the upper part of the chart, the plants that use diverse oilseeds to obtain biodiesel are close to the production of other (non-food) outputs in the same firm.

Fig. 4. Joint plot of category points

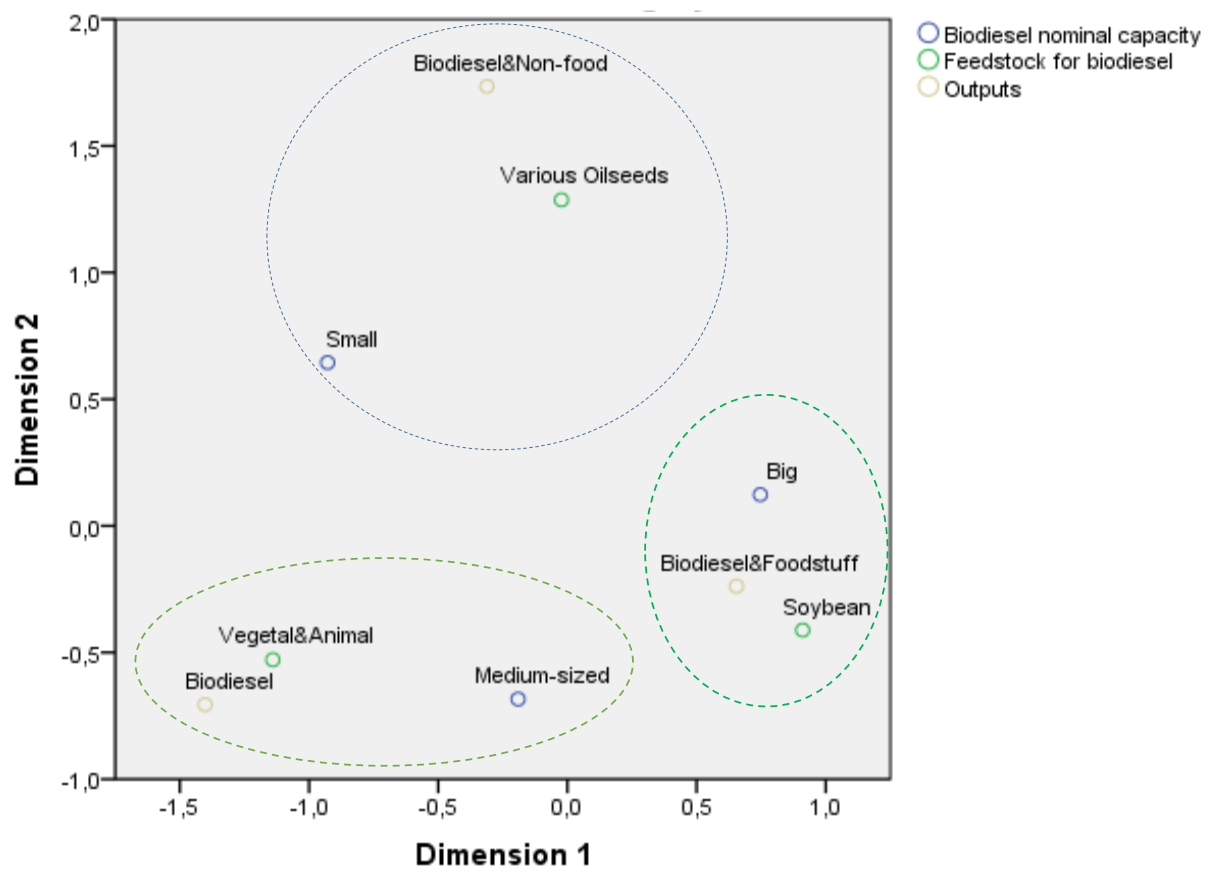

Source: Authors' elaboration.

The MCA also calculates the coordinates of each object (biodiesel plant) in the same two-dimensional space. The second step of our analysis is to take these object scores as grouping variables for an agglomerative hierarchical clustering (Carvalho, 2008), in order to identify relatively homogeneous groups of biodiesel plants. This type of clustering suits for a small number of objects; more specifically, we have selected the Ward method, which minimises the variance of the distance of the objects to cluster centroids (Ward, 1963).

The number of clusters is determined with the help of the SPSS-derived dendrogram (Fig. 5), a tree graph that represents the different stages of the clustering process and the distance among the objects clustered in each stage. In the first stages of the procedure the objects combined are very homogeneous, and more dissimilar clusters are merged as we move to the right. The dendrogram 
obtained in our study makes it evident that the grouping process should stop in three clusters, as there is a clear jump in the distance (i.e. the heterogeneity) between this and the following clustering step.

Fig. 5. Dendrogram using Ward linkage - rescaled distance cluster combine.

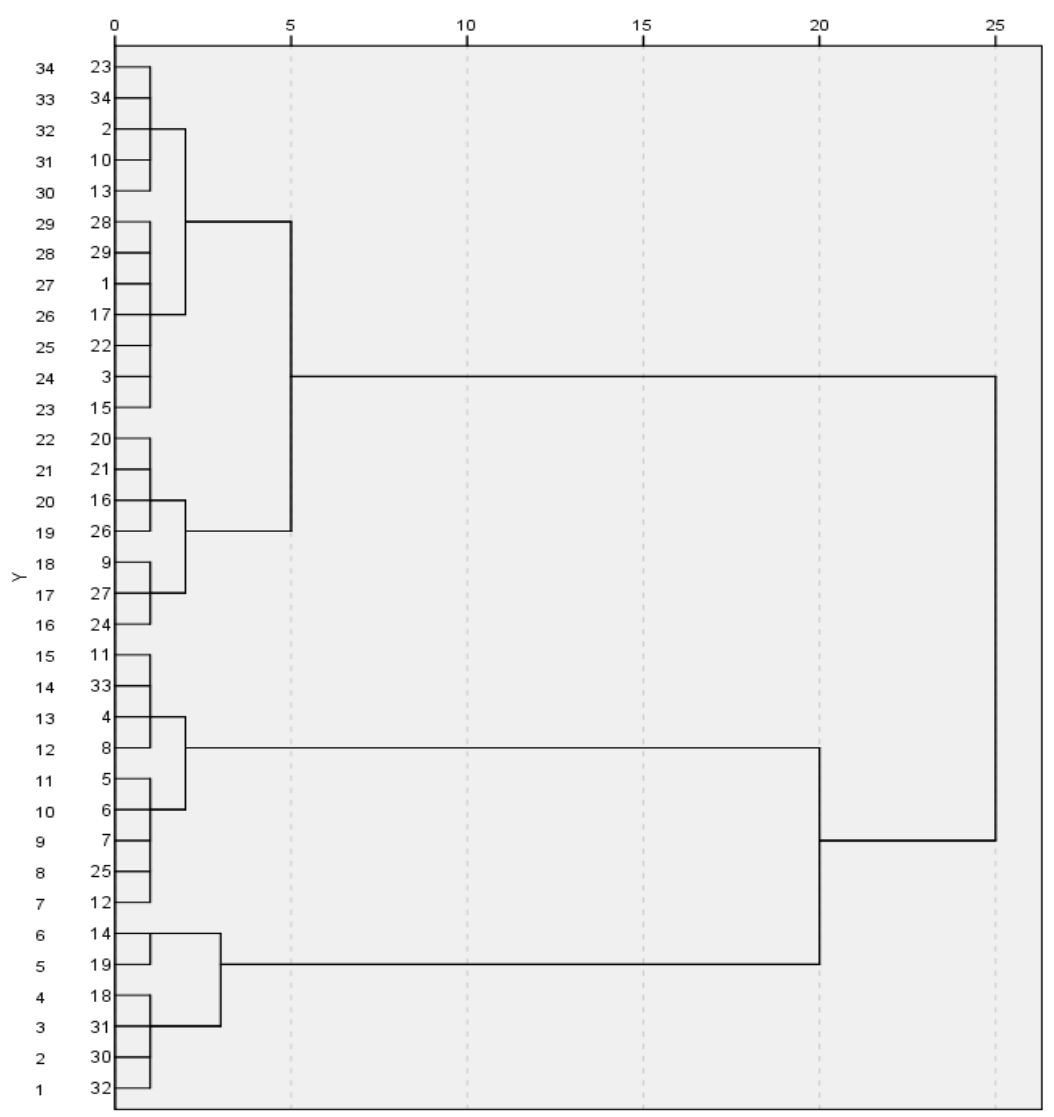

Source: Authors' elaboration.

The clusters are characterised in Table 4, which shows the number of biodiesel plants that fall in each category, and some complementary information about them such as the regions where they operate and the average volume of biodiesel delivered in the auctions. Further information obtained from the website of the industries or provided directly by them has been used to complete the description and discuss the results of the analysis. 
Table 4. Clusters of biodiesel plants in Brazil, 2016

\begin{tabular}{|llccc|}
\hline & Small & $\begin{array}{c}\text { Cluster 1 } \\
(\mathrm{n}=19)\end{array}$ & $\begin{array}{c}\text { Cluster 2 } \\
(\mathrm{n}=9)\end{array}$ & $\begin{array}{c}\text { Cluster 3 } \\
(\mathrm{n}=6)\end{array}$ \\
\hline \multirow{3}{*}{ Nominal capacity } & Medium & 1 & 4 & 4 \\
& Big & 6 & 4 & 1 \\
& Average $\left(\mathrm{m}^{3}\right)$ & 12 & 1 & 1 \\
\hline \multirow{3}{*}{ Feedstock for biodiesel } & Soybean & 236,697 & 132,640 & 113,673 \\
& Various Oilseeds & 14 & 0 & 0 \\
& Vegetal \& Animal Feedstock & 1 & 0 & 5 \\
\hline \multirow{3}{*}{ Outputs produced } & Biodiesel & 0 & 7 & 1 \\
& Biodiesel \& Foodstuff & 18 & 2 & 0 \\
& Biodiesel \& Non-food & 1 & 0 & 5 \\
\hline \multirow{2}{*}{ Biodiesel delivered ${ }^{\mathrm{a}}\left(\mathrm{m}^{3}\right)$} & & 136,159 & 87,805 & 60,785 \\
\hline & & 1 & 0 & 0 \\
& North & 1 & 0 & 2 \\
& Northeast & 8 & 5 & 2 \\
Region & Central-West & 2 & 0 & 2 \\
& Southeast & 7 & 4 & 0 \\
\hline
\end{tabular}

${ }^{\mathrm{a}}$ Given that the biodiesel delivered by the plants largely varies from year to year, we have used the average of biodiesel delivered in 2015 and 2016.

Source: Authors' elaboration.

Cluster 1 is the most numerous group and includes nearly all the plants falling into the category 'big' the average nominal capacity thus far exceeds that of the others. These plants typically utilise soybean as the only feedstock for biodiesel and have an oil extraction plant annexed to the biodiesel plant. They belong to multi-output firms also producing foodstuff (such as oils, sugar, meat, cereals, flour and soy protein concentrate), and sometimes non-food products (ethanol, cotton and agricultural inputs seeds, pesticides and fertilizers). Exceptionally, some firms are involved in broader businesses such as gas, coal and metal mining. Some regional branches of large agri-food industries (ADM and GRANOL) are included here. 
Cluster 2 is characterised by the utilisation of animal fat as a feedstock to obtain biodiesel, although a mix of other oilseeds (mainly soybeans, but also cotton or canola) or waste oil are also utilised. Most of these plants belong to firms specialised in the production of biodiesel. According to the information they provided to us, the beef tallow used as raw material does not come from a food division of the same company, but is purchased from third firms. In terms of scale, there are either small or medium sized plants, and their average nominal capacity is intermediate between the two other clusters.

Cluster 3 has the least plants and shows the smallest average size of the three groups. These mills produce biodiesel from a variety of oilseeds, and belong to firms that are also involved in the production of ethanol from sugar cane, electric energy or a variety of products from tin, antimony and zinc. The three Pbio plants - branches of the state-led company, Petrobras - fall in this cluster.

Fig. 6. Map of biodiesel plants operating in Brazil in 2016, grouped by clusters

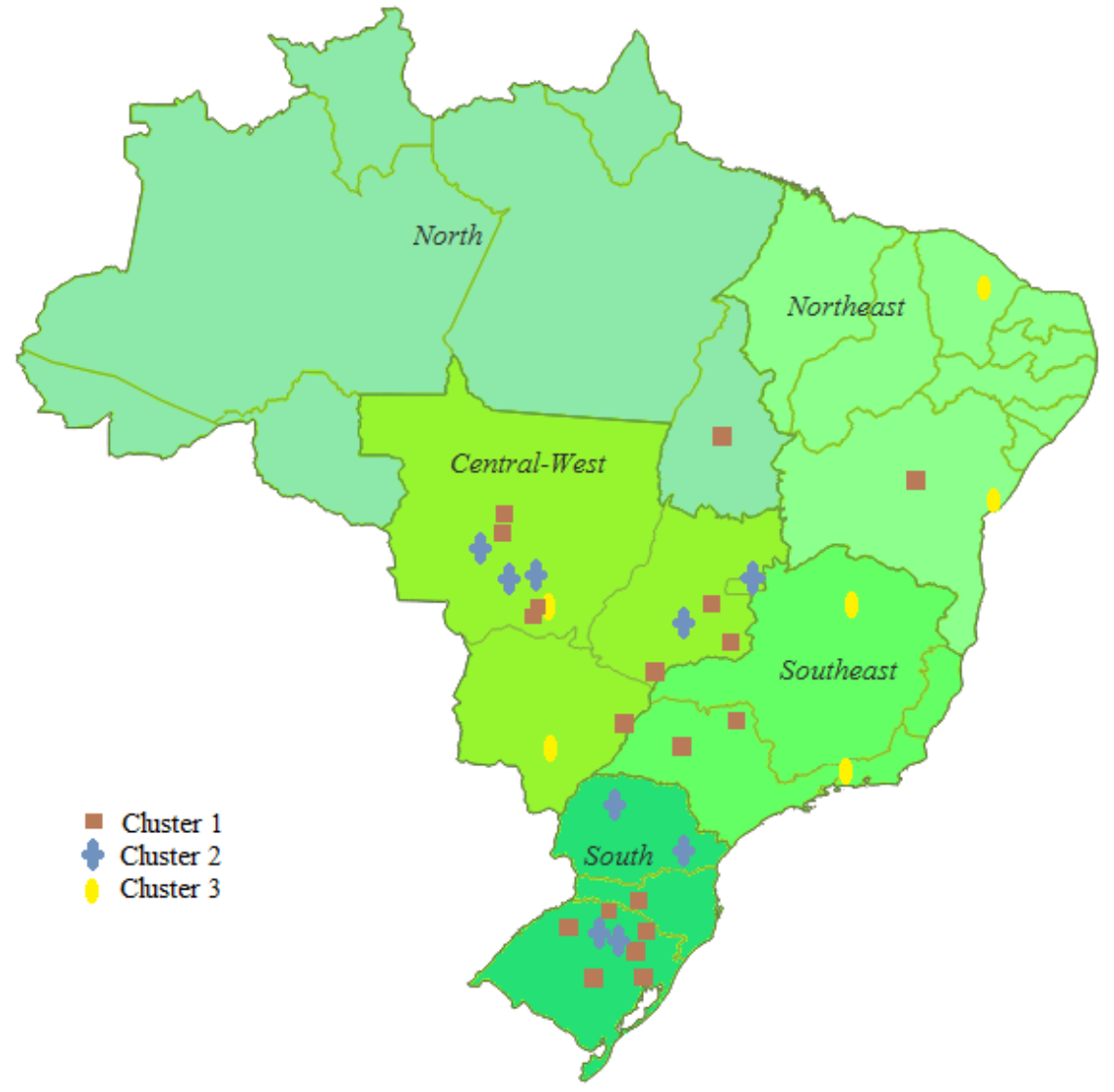

Source: Authors' elaboration. 
Regarding the geographical distribution of the 34 plants operating in Brazil, Fig. 6 shows that they are markedly concentrated in the Central-West (15) and the South (11) of the country, where the large agri-food businesses producing biodiesel and foodstuff from soybeans (cluster 1) prevail. However, plants falling in cluster 2 -that use animal tallow as feedstock - are also strongly concentrated in the same regions. Technicians of these industries have confirmed to us that animal fats have become the preferred feedstock to ensure off-season supply in soybean-producing areas. Meanwhile, the few small plants of cluster 3 that produce biodiesel from diversified crops are present in underrepresented regions such as Northeast and Southeast.

\section{Conclusion and Policy Implications}

The Brazilian biofuel industry has developed under a complex regulatory framework aimed to boost this sector since it was launched in 2004. Data on the evolution of this industry clearly show that the combination of institutional tools embraced by the PNPB (auctions, blending mandates and tax incentives) has been successful in promoting the entrance of companies and the expansion of biodiesel production, making Brazil a world reference in this industry. Nevertheless, the programme also pursued other objectives -territorial balance of production, integration of small farmers in the value chain and diversification of raw materials - which have not been achieved satisfactorily. Indeed, the involvement of family farmers remains much below expectations, soybeans are still by far the main feedstock, and power plants are increasingly concentrated in soy producing regions close to biodiesel consumption centres. Despite the production growth over the years, biodiesel plants still work at half of their installed capacity, although the utilisation factor should improve with the upcoming increases in the blend rates and the expected recovery of the Brazilian economy (Barros, 2016). 
Regarding the evolution of the industrial structure, this work has allowed to close the time gap with previous studies on this matter. Our analysis has allowed for the identification of two main subperiods. The first one (from 2005 to 2011) was marked by a rapid increase in the volume of biodiesel produced, the entrance of new companies and a gradual de-concentration. The second one -beyond the time scope of the abovementioned studies - starts in 2012 and shows a very different picture, as the productive expansion was carried out by fewer companies and plants. This trend would be associated to the narrowing of the profit margins reported by different scholars (Oliveira and Coelho, 2016; Nogueira et al., 2016), and to the increasing competition promoted by the changes in the auction model introduced in 2012. The stability of the concentration indexes in this period points to the homogenisation of the plant scales.

Finally, the multivariate analysis conducted to classify biodiesel plants has identified a set of different 'business models'. The first one (represented by cluster 1) is characterised by input specialisation and output diversification, i.e. companies utilising soybean as raw material to produce biodiesel and foodstuff, and often involved in broader businesses. The second is a model of input diversification and output specialisation, i.e. companies specialised in biodiesel that need to diversify feedstocks to ensure the supply throughout the year, mainly buying beef tallow to other firms as cheap alternative to soybeans. Finally, a reduced group of relatively small power plants (cluster 3) use diversified crops to produce biodiesel, and are not coupled with food processing plants -PBio plants fall in this category.

In short, this paper has shown how the firms that shape the Brazilian biodiesel industry have rapidly evolved under the initial regulatory framework of the PNPB, and today display different and flexible business models. The industry structure that we have outlined here is the setting where the RenovaBio 2030 programme, now under debate, will be developed.

\section{Acknowledgments}

This work was supported by the Capes Foundation - Ministry of Education of Brazil [grant numbers BEX 9604/13-8]. 


\section{References}

ANP, 2017. Agência Nacional do Petróleo, Gás Natural e Biocombustíveis, Resultados de todos os Leilões Realizados; Unidades produtoras - Dados das Entregas dos Leilões. Legislação biodiesel. <http://www.anp.gov.br/?id=472> (Accessed 10 April 2017).

Bain, J.S., 1951. Relation of Profit Rate to Industry Concentration: American Manufacturing, 19361940. Q. J. Econ. 65 (3), 293-324.

Barros, S., 2016. Biofuels Annual. USDA. GAIN Report No. BR15006. Brazil.

Bergmann, J.C., Tupinambá, D.D., Costa, O.Y.A., Almeida, J.R.M., Barreto, C.C., Quirino, B.F., 2013. Biodiesel production in Brazil and alternative biomass feedstocks. Renew. Sust. Energ. Rev. 21, 411420.

Biodieselbr, 2009. Venda da Agrenco: valores e vantagens.

<http://www.biodieselbr.com/biodiesel/analises/23mar09-venda-agrenco-valores-vantagens.htm> (Accessed 10 April 2017).

Biodieselbr, 2012. Oleoplan vende usina de biodiesel.

<http://www.biodieselbr.com/noticias/usinas/info/oleoplan-vende-usina-031012.htm> (Accessed 10 April 2017).

Biodieselbr, 2014a. V-Biodiesel agora se chama Oleoplan Nordeste.

<http://www.biodieselbr.com/noticias/usinas/info/v-biodiesel-agora-chama-oleoplan-nordeste081014.htm> (Accessed 10 April 2017).

Biodieselbr, 2014b. Granol amplia parceria com agricultores familiares no TO. <http://www.biodieselbr.com/noticias/usinas/info/granol-amplia-parceria-agricultores-familiares$\underline{\text { to060214.htm }}>$ (Accessed 10 April 2017).

Biodioselbr, 2016. Olfar vai dobrar capacidade de usina do Rio de Janeiro. <https://www.biodieselbr.com/noticias/usinas/aut/olfar-dobrar-capacidade-usina-rio-janeiro201016.htm> (Accessed 10 April 2017). 
Carvalho, H., 2008. Análise Multivariada de Dados Qualitativos. Utilização da Análise de Correspondências Múltiplas com o SPSS, second ed. Lisboa.

César, A.S., Batalha, M.O., Zopelari, A.L.M.S., 2013. Oil palm biodiesel: Brazil’s main challenges. Energy 60 (1), 485-491.

Cremonez, P.A., Feroldi, M., Nadaleti, W.C., de Rossi, E., Feiden, A., de Camargo, M.P., Cremonez, F.E., Klajn F.F, 2015. Biodiesel production in Brazil: Current scenario and perspectives. Renew. Sust. Energ. Rev. 42, 415-428.

Dos Santos, M.S., Padula, A.D., 2012. Industrial dynamics of biodiesel industry in Brazil. Gestão Contemporânea, Porto Alegre 12, 293-312.

Greenacre, M.J., 1984. Theory and applications of correspondence analysis. Academic Press. London. Hirschman, A.O., 1964. The Paternity of an Index. The American Economic Review 54 (5), p. 761.

Law no. 11.097, Official Gazette of the Union (D.O.U.), 14.1.2005. <http://nxt.anp.gov.br/NXT/gateway.dll/leg/leis/2005/lei\%2011.097\%20\%202005.xml?f=templates\$fn=default.htm\&sync=1\&vid=anp:10.1048/enu> (Accessed 10 April 2017). Leonardi, A., Scarton, L.M., Padula, A.D., Coronel, D.A., 2011. A concentração do mercado de biodiesel no Brasil. Perspectiva Econômica 7 (1), 55-63.

Marcossi, G.P.C., Moreno-Pérez, O.M., 2017. A closer look at the Brazilian Social Fuel Seal: uptake, operation and dysfunctions. Biofuels. In Press.

MDA, 2016. Ministério do Desenvolvimento Agrário. Selo Combustível Social, Balanço 2015, Gráficos ajustados.

<http://www.mda.gov.br/sitemda/sites/sitemda/files/user img 21/SCS BALANCO 2015 PARA PU BLICACAO.pdf> (Accessed 10 April 2017).

MME, 2015. Ministério de Minas e Energia, Secretaria de Petróleo, Gás Natural e Combustíveis Renováveis.

<http://www.mme.gov.br/programas/biodiesel/menu/programa/objetivos diretrizes.html> (Accessed 10 April 2017). 
MME, 2016. Ministério de Minas e Energia, Secretaria de Petróleo, Gás Natural e Combustíveis Renováveis. Bulletin n. 106, December 2016.

<http://www.mme.gov.br/web/guest/secretarias/petroleo-gas-natural-e-combustiveisrenovaveis/publicacoes/boletim-mensal-de-combustiveis-renovaveis> (Accessed 10 April 2017). Nogueira, L.A.H., Capaz, R.S, 2013. Biofuels in Brazil: Evolution, achievements and perspectives on food security. Glob. Food Secur. 2 (2), 117-125.

Nogueira, L.A.H., Capaz, R.S., Souza, S.P., Seabra, J.E.A., 2016. Biodiesel Program in Brazil: Learning curve over ten years (2005-2015). On the Map. Biofuels, Bioprod. Bioref. 10, 728-737.

Oliveira, F.C. and Coelho, S.T., 2016. History, evolution, and environmental impact of biodiesel in Brazil: A review. Renew. Sust. Energ. Rev. Article in Press.

Oliveira, H.R., Leal, J.E.C., Abreu, Y.V., 2012. Biodiesel no Brasil em três hiatos: Selo Combustível Social, Empresas e Leilões. 2005 a 2012. Eumed.net. Universidad de Málaga. Málaga.

Ordinance no 276, MME. Decree No. 2761, Official Gazette of the Union (D.O.U.) 11.5.2012.

Ordinance no. 337, MDA, Official Gazette of the Union (D.O.U.), 18.9.2015. Dispõe sobre os critérios e procedimentos relativos à concessão, manutenção e uso do Selo Combustível Social.

Padula, A.D., Santos, M.S., Ferreira, L., Borenstein, D., 2012. The emergence of the biodiesel industry in Brazil: Current figures and future prospects. Energ. Policy, 44, 395-405.

REN21, 2016. Renewables 2016 Global Status Report. Paris. REN21 Secretariat.

Rico, J.A.P., Sauer, I.L, 2015. A review of Brazilian biodiesel experiences. Renew. Sust. Energ. Rev. 45, $513-529$.

Silva Jr., D., 2013. Impacts of biodiesel on the Brazilian fuel market. Energ. Econ. 36, 666-675.

Silva, M.S., Fernandes, F.M., Teixeira, F.L.C., 2014. Biodiesel and the "Social Fuel Seal" in Brazil: Fuel of Social Inclusion? J. Agr. Sci. 6 (11), 212-228.

Stattman, S.L., Hospes, O., Mol, A.P.J., 2013. Governing biofuels in Brazil: A comparison of ethanol and biodiesel policies. Energ. Policy, 61, 22-30. 
Stattman, S.L., Mol, A.P.J., 2014. Social sustainability of Brazilian biodiesel: The role of agricultural cooperatives. Geoforum, 54, 282-294.

Tanaca, E.K.T., de Souza, J.D.F., 2010. Análise da concentração industrial dos leilões de biodiesel. XXX Encontro Nacional de Engenharia de Produção. Maturidade e desafíos da Engenharia de Produção: competitividade das empresas, condições de trabalho, meio ambiente. São Carlos, SP, Brasil, 12 to 15 october 2010.

Ward Jr., J.H., 1963. Hierarchical Grouping to Optimize an Objective Function. J. Am. Stat. Assoc. 58, $236-244$. 